\title{
Ludwik Stanisław Szuba, Harcerstwo na Pomorzu $i$ Kujawach w latach 1945-1950 w świetle dokumentów Wojewódzkiego Urzędu Bezpieczeń- stwa Publicznego w Bydgoszczy, Bydgoszcz 2006, ss. 274
}

Prezentowana praca L. S. Szuby pt. Harcerstwo na Pomorzu i Kujawach $w$ latach 1945-1950 w świetle dokumentów Wojewódzkiego Urzędu Bezpieczeństwa Publicznego w Bydgoszczy jest bezsprzecznie publikacją bardzo cenną. I to przynajmniej z dwóch względów: po pierwsze, jak zresztą zauważa sam Autor we „Wstępie”, dzięki odtajnieniu materiałów archiwalnych jest szansa na „rzucenie” nowego światła na powojenne, bardzo dramatyczne losy polskiego harcerstwa, a jednocześnie ukazanie prawdziwego oblicza nowej wówczas, „ludowej” władzy i poczynań organów bezpieczeństwa „najbardziej zbrodniczego ramienia PPR/PZPR w Polsce Ludowej". Po wtóre natomiast, omawiana książka stanowi cenną pozycję jako baza źródłowa do kontynuowania badań regionalnych.

W oparciu o najnowsze, ,zdobycze" archiwalne dotyczące okresu stalinowskiego w Polsce powstało do tej pory niewiele pozycji książkowych dotyczących harcerstwa, przeważają właśnie wydawnictwa źródłowe, głównie o charakterze wspomnieniowym ${ }^{1}$. Jest to temat przede wszystkim odrobinę niebezpieczny, a także trudny. Brakuje bowiem dystansu historycznego, który pogrzebałby spory ideologiczne, uporządkowałby także kwestie wiarygodności zachowanych źródeł. Wiadomo bowiem, że nie wszystkie dokumenty wytwarzane przez „bezpiekę” są wiarygodne i prawdziwe, co zresztą sam Autor podkreśla, pisząc, że „Dzieje harcerzy przedstawione w książce oparte są w głównej mierze na subiektywnych donosach agentury i informatorów oraz różnego szczebla funkcjonariuszy UB, dlatego też mogą się $\mathrm{w}$ niej znaleźć pewne przekłamania, zwłaszcza podczas przedstawiania nazwisk czy ocenie politycznej i moralnej harcerzy"2.

Praca L. S. Szuby ma zatem podwójną wartość - odkrywa już dziś „białe plamy”, a także może w przyszłości stanowić doskonały materiał badawczy, szczególnie dla młodych dziejopisów, wolnych od uprzedzeń i subiektywnych wspomnień.

$\mathrm{Na}$ uwagę zasługuje plan i logiczność całej publikacji. Autor bowiem nie poszedł „na łatwiznę" - zanim zaprezentował nieznane dokumenty w dwóch pierwszych rozdziałach pracy najpierw przybliża historię harcerstwa (pierwszy rozdział), a także lata Polski powojennej, tj. okres 1945-1950, a dokładniej działalność Pomorskiej Komendy Chorągwi w Bydgoszczy (drugi rozdział). I dopiero na szerokim tle dziejowym umieszcza źródła.

Trzeci rozdział prezentuje działalność harcerstwa w terenie. Wzięte zostały pod uwagę najważniejsze miejscowości regionu: Aleksandrów Kujawski, Brodnica, Chełmno, Chojnice, Grudziądz, Inowrocław, Rypin, Sępólno, Świecie, Szubin, Torun, Tuchola, Wąbrzeźno i Włocławek. Pominięte zostały jedynie te miejscowości, do których nie ma materiałów źródłowych.

\footnotetext{
${ }^{1}$ Patrz np.: Sowieckiemu zniewoleniu „NIE”. Harcerska druga konspiracja 1944-1956, praca zbiorowa z przedmową S. Broniewskiego „Orszy", Wydawnictwo Ład, Warszawa 2005.

${ }^{2}$ Ibidem, 191.
} 
Częścią nie mniej interesującą jest kolejny rozdział - czwarty. Stanowi go lista harcerzy uznanych przez Urząd Bezpieczeństwa za wrogo ustosunkowanych do demokracji i nowej władzy ludowej. Rozdział ten pokazuje jak bardzo niebezpieczna była jakakolwiek działalnosć w powojennym okresie i jak głęboka była inwigilacja polskiego społeczeństwa. Przy każdym bowiem harcerskim nazwisku znajduje się mniej lub bardziej rozbudowana charakterystyka osoby, jej działalności, wnikliwa ocena postawy życiowej. Szczególnie surowo, co dzisiaj wydaje się dość zrozumiałe, oceniona została aktywność harcerska księży.

W ogólnej ocenie, w świetle przytoczonych dokumentów, władza ludowa traktowała harcerstwo bardzo podejrzliwie i wrogo. Podobnie odnosiła się także, a może przede wszystkim do jego skautowych tradycji i powiazzan. W jednym z prezentowanych przez autora dokumentów czytamy bowiem: „Koncepcja skautingu zrodziła się w ogniu imperialistycznej wojny prowadzonej przez Anglików przeciwko chłopom holenderskim, kolonistom Południowej Afryki. Charakter pomocniczej służby zorganizowanej pod Mafekingiem młodzieży w oddziały zwiadowcze, łączników, wartowników, nakreślił kierunek wychowawczy organizacji skautowych całego świata. Skauting na przestrzeni lat swojego istnienia przedstawiał zawsze kierunek nacjonalistyczny, antyrewolucyjny, związany służbą dla burżuazji, wychowujący lojalnych i wiernych obrońców ustroju kapitalistycznego"3. Przy tak negatywnym stosunku do historii nie sposób było nowej władzy zaakceptować i zrozumieć założeń ideowo-politycznych i społecznych zwalczanej organizacji, jej podstaw filozoficznych, celów wychowania, metodyki harcerskiej, które wszędzie indziej poza „blokiem wschodnim” okazywały się ponadczasowe i uniwersalne. Logiczne zatem w tym kontekście wydają się być zabiegi, mające na celu likwidację harcerstwa, co zresztą nastąpiło w $1950 \mathrm{r}$. Bolesne przy tym jest jednak to, że aktywny udział w tym barbarzyńskim procederze brali udział przedwojenni jeszcze działacze harcerscy (Pelagia Lewińska). Ten fakt uwydatnia jeszcze grozę tamtych dni i siłę propagandy komunistycznej.

W zakończeniu Autor stawia bardzo interesującą i mającą ,pokrycie” w dokumentach tezę, iż prześladowanie harcerstwa nie rozpoczęło się w czasie „ofensywy ideologicznej PZPR" w 1948 r., ale znacznie wcześniej, zaraz po zakończeniu działań wojennych. Wkrótce potem także ludowa władza rozpoczęła inwigilację działaczy harcerskich, ich werbowanie do współpracy z „bezpieką”, a tym samym także ich weryfikowanie. Pozytywną informacją jest jednak to, że proces przechwytywania harcerstwa nie był zupełnie dla władzy bezbolesny - wszelkie zmiany w organizacji natrafiały bowiem zawsze na stanowczy opór harcerzy.

Bardzo dokładnie publikacja została przygotowana edytorsko - w przypisach znalazły się dodatkowe informacje, przydatne do zrozumienia całości zagadnienia. Ponadto Autor zamieścił część dokumentów w aneksach, co pozwoliło mu na ich cytowanie w całości. L. S. Szuba zestawił także aneks nazwisk oraz sporządził wykaz funkcjonariuszy Pomorskich Urzędów Bezpieczeństwa i wykaz używanych w tekście skrótów. Dodatkowym walorem prezentowanej pracy są fotografie.

\footnotetext{
${ }^{3}$ Ibidem, 206.
} 
Wysiłek L. S. Szuby, w moim przekonaniu, nie został zmarnowany i zasługuje na uwagę czytelników, szczególnie tych, którym losy harcerstwa nie są obojętne. Praca o harcerstwie na Pomorzu i Kujawach w latach 1945-1950 pokazuje nie tylko jałowe i bezpłodne wysiłki ludowej władzy, która wydała wojnę dzieciom i młodzieży, wręcz przeciwnie, uwiarygodnia tezę, że wychowywanie mądrych i odpowiedzialnych obywateli kończy się z chwilą, gdy nadrzędną wartością staje się polityka i ideologia.

Edyta Glowacka-Sobiech

\section{Wladysława Szulakiewicz, Historia oświaty $i$ wychowania $w$ Polsce 1944-1956, Kraków 2006, ss. 311}

Książka Władysławy Szulakiewicz - znanej badaczki dziejów edukacji i reprezentantki dyscypliny naukowej, której dzieje te są przedmiotem zainteresowań - została poświęcona polskiej historii wychowania lat 1944-1956. Jest to okres szczególny w rozwoju polskiej nauki, także i historii wychowania. Jego początek, zbiegający się z końcem II wojny światowej i wyzwalaniem spod okupacji niemieckiej ziem polskich, łączy się także z odbudową życia naukowego, reaktywacją działalności badawczej w dotychczasowych ośrodkach naukowych i kształtowaniem się nowych ośrodków naukowych (w tym na tzw. Ziemiach Odzyskanych). W trudnych powojennych warunkach ekonomicznych, społecznych i politycznych podejmowany jest $w$ wielu środowiskach naukowych często heroiczny - nie pozbawiony optymizmu - wysiłek organizacyjny i badawczy. Jednak z upływem czasu, zwłaszcza po 1948 r., następuje - w warunkach wzrastającej sowietyzacji kraju - ograniczanie autonomii nauki polskiej lub wręcz unicestwianie niewygodnych i niepokornych ośrodków nauki. Poprawa $\mathrm{w}$ tym zakresie nastąpi dopiero po znanych wydarzeniach politycznych $1956 \mathrm{r}$.

Publikacja została oparta na szerokich podstawach źródłowych. Na pierwszym miejscu wymienić należy piśmiennictwo historyczno-oświatowe omawianego w książce okresu (monografie, studia, artykuły, recenzje). Autorka wykorzystuje także inne źródła drukowane (w tym wspomnienia). Sięga w szerokim zakresie również do materiałów archiwalnych znajdujących się w zasobach Archiwum Akt Nowych, archiwach Polskiej Akademii Nauk (w Warszawie, Krakowie), Archiwum Uniwersytetu Jagiellońskiego, Archiwum UMCS w Lublinie, Archiwum UMK w Toruniu, Archiwum Uniwersytetu Lódzkiego, Archiwum Uniwersytetu Warszawskiego, Archiwum Uniwersytetu Wrocławskiego, Archiwum Uniwersytetu Poznańskiego i Archiwum Akademii Pedagogicznej w Krakowie. Autorka korzysta także - w sposób krytyczny - $\mathrm{z}$ dotychczasowego dorobku badawczego (dotyczącego rozwoju polskiej historiografii, głównie odnoszącego się do powojennej historii wychowania i powojennych historyków wychowania).

Struktura książki, oparta - w swojej zasadniczej części - na kryterium problemowym jako pierwszoplanowym, jest klarowna i w pełni uzasadniona. Obejmuje sześć rozdziałów. W rozdziale pierwszym stanowiącym swoiste wprowadzenie do dalszych rozważań Autorka wykracza poza przyjęte ramy chronologiczne, sięga bowiem do okresu wojny i okupacji ukazując straty osobowe $i$ materialne omawianej w pracy dyscypliny 